\title{
Environmental survival and microbicide inactivation of coronaviruses
}

\author{
Manfred H. Wolff, ${ }^{1}$ Syed A. Sattar, ${ }^{2}$ Olusola Adegbunrin ${ }^{2}$ and Jason Tetro ${ }^{2}$ \\ ${ }^{1}$ Faculty of Bioscience, Institute of Microbiology and Virology, Stockumer Str. 10, D-58453 \\ Witten, Germany \\ ${ }^{2}$ Centre for Research on Environmental Microbiology (CREM), Faculty of Medicine, \\ University of Ottawa, Ottawa, Ontario, Canada K1 H 8 M5
}

\section{Introduction}

Since their first isolation from chickens in 1937 [1], coronaviruses have proven to be significant pathogens of many types of wild as well as economically important domesticated animals. Though coronaviruses were first identified as human respiratory pathogens in 1965 [2], only recently, with their established link with the severe acute respiratory syndrome (SARS), has there been a sudden upsurge of interest in this group of viruses.

Taxonomically, these enveloped, positive-sense RNA viruses [1] belong in the genus Coronavirus of the family Coronaviridae in the order Nidovirales [3]. To date, the genus contains some 14 members. Birds and mammals are the known hosts with a wide variety of species affected. In mammals, coronaviruses have been isolated from pigs, cattle, mice, rats, dogs, horses, cats, and humans [1], and in birds mainly from chickens [4] and turkeys [5].

Coronaviruses 229E and OC43 are recognized respiratory pathogens of humans. The causative agent of SARS (SARS-CoV), which has now been fully characterized [6], awaits its formal inclusion in the genus. Genomic studies show SARS-CoV to be unique as it contains elements of both mammalian and avian ancestry [7] and the effect of this recombination has been disastrous for humans. In the first recorded outbreak in 2003, the virus caused 8,461 clinical cases and 804 recorded deaths globally [8]. Fortunately, and in spite of its seemingly high mutation rates [9], the spread of the virus was effectively controlled, mainly through general public health measures and basic infection control practices. Nevertheless, the SARS incident has had a significant impact on human health and the global economy [10] and thus highlighted the need to better understand the modes and vehicles for its spread and proper means to interrupt its environmental transmission. 


\section{Pathogenesis and shedding of infectious virus}

Depending on the type of coronavirus and the animal host species, virus shedding can occur from the respiratory and/or gastrointestinal tract [11] and the two main portals of virus entry into susceptible animals are the nose and the mouth [12]. In humans, coronaviruses normally cause the common cold, SARS being a notable exception because it causes severe pneumonia as well as acute gastroenteritis. The risk of environmental contamination with the SARS-CoV is thus much higher. The evidence available thus far from outbreak investigations is strongly suggestive of droplet transmission [13] and to a much limited degree by aerosols [14]. It is not known if the SARS-CoV can also be acquired through the mouth or the conjunctivae, nor do we know if inhaled virus deposited in the throat can be directly translocated to the gut.

In SARS, massive spiking of the immunological response leads to hypoxia and eventual respiratory distress syndrome [15]. Infection of the gastrointestinal tract causes acute diarrhea and may also result in peritonitis and necrotizing colitis [16]. The simultaneous involvement of the respiratory as well as the gastrointestinal tracts in SARS [11] is highly reminiscent of coronavirus infections in cattle [17] and other animals.

Based on the pig model, the infectious period for coronaviruses is approximately 6 days post-infection $[12,18]$ with a peak at day 4 post-infection. This holds true for bovine [17, 19] and human infections [20,21] as well. In pigs, virus release from the nose peaks on the fourth day of infection with yields of $>5.5 \log _{10} \mathrm{TCID}_{50} / \mathrm{g}$ of nasal discharge, with the air around such animals containing nearly $2 \log _{10}$ of infectious virus $/ \mathrm{m}^{3}$ [12]. Similarly, infectious virus has been detected in the nasal discharge and feces of SARS patients [11].

\section{Environmental survival and spread of coronaviruses}

In general, a given pathogen must remain viable outside the host to allow for environmental spread, and the combined effect of many biotic and abiotic factors determines how long such viability can be retained. While environmental survival of coronaviruses has been studied to some degree under experimental conditions [22, 23] including SARS (Tab. 1), we know much less about the types and relative significance of vehicles in the in-nature spread of coronaviruses, in particular those that can infect humans. For example, infectious virus has been recovered from both droplets and air in the vicinity of pigs experimentally infected with the porcine respiratory coronavirus [12], but the potential, if any, of droplets and aerosols in the spread of the virus to susceptible animals in the vicinity is unknown.

The following is a summary of the available information on the environmental survival and spread of coronaviruses. 
Table 1. Environmental survival of SARS-CoV (modified from [20]

\begin{tabular}{lc}
\hline Environment & $\begin{array}{c}\text { Number of hours } \\
\text { virus infectivity remained detectable }\end{array}$ \\
\hline Cell culture fluid at $4^{\circ} \mathrm{C}$ & Fluid \\
Cell culture fluid at room temperature & $>120$ \\
Autoclaved water & 60 \\
Serum & 72 \\
Sputum & 72 \\
Feces & 96 \\
Urine & 96 \\
\hline
\end{tabular}

\begin{tabular}{lc}
\hline & Non-porous environmental surface \\
Glass & 60 \\
Mosaic & 60 \\
Metal & 72 \\
Plastic & 60 \\
\hline & \\
Cloth & Porous materials \\
Filter paper & 72 \\
Autoclaved soil (Beijing, China) & 72 \\
\hline
\end{tabular}

Air

The effect of relative humidity $(\mathrm{RH})$ and air temperature has been studied on the airborne survival of experimentally aerosolized human coronavirus 229E [22]. As is true for enveloped viruses in general, 229E survived better at $30-50 \% \mathrm{RH}$ than at $80 \% \mathrm{RH}$ when the air temperature was about $20^{\circ} \mathrm{C}$. Under these conditions, the half-lives of the virus at $30 \%, 50 \%$ and $80 \%$ RH were 27, 67 and 3 hours, respectively. Lowering the air temperature to $6{ }^{\circ} \mathrm{C}$ increased the half-lives of the virus at $30 \%$ and $50 \% \mathrm{RH}$ to 34 and 103 hours, respectively. But the lower air temperature produced the most dramatic effect on virus survival at $80 \% \mathrm{RH}$ and changed its half-life from 3 to over 86 hours.

The available epidemiological evidence strongly suggests that SARS spreads through droplets [13] and such spread is much easier to control than that through aerosols. However, the pattern of spread of SARS-CoV in at least two instances is highly suggestive of airborne spread.

A cluster of 329 SARS cases was recorded in one apartment complex in Hong Kong with the majority of them occurring on several floors in one wing [24]. This pattern of spread is highly suggestive of virus dissemination by air, and the aerosolization of the virus was speculated to have occurred 
from malfunctioning sewers in the building [24]. Rodent pests in the building have been hypothesized as possible amplifiers and disseminators of the virus [25]; the virus, most likely acquired from infected residents, may have multiplied in the rodents, being released in their excreta and then possibly becoming airborne. While hantaviruses, for example, can infect humans from aerosolized rodent excreta [26], the role of air in the transmission of SARS-CoV in this outbreak remains speculative at this stage. However, a more detailed analysis of the outbreak of SARS at that apartment complex suggests that the virus released by the patients themselves may have spread through air [27].

Limited airborne spread of SARS may have occurred on board commercial aircraft. In one such instance, a symptomatic index case infected at least 22 of $120(18.3 \%)$ passengers and crew during a three-hour flight [14]. Some of those infected were seated over $2 \mathrm{~m}$ (90 inches) away from the index case, a distance much longer than the $0.9 \mathrm{~m}$ (36 inches) generally believed to be the limit for droplet transmission. In such retrospective investigations it is virtually impossible to rule out the role of other possible means of virus spread. Also, the inside of an aircraft combines features which may be more conducive to airborne spread of pathogens.

A recent report from Canada suggests that oxygen delivery masks with open vents could promote the dispersal of respiratory pathogens such as SARS-CoV through their enhanced release in mists of exhaled pulmonary gases [28]. The exhaled moist air ejected from such oxygen masks is believed to carry pathogen-laden droplets over longer distances and possibly contribute to an increased risk of spread of respiratory infections in nosocomial settings. Additional investigations are needed to first prove that viruses such SARS-CoV can retain their infectivity better in the warm, moisture-laden air exhaled from oxygen masks. The findings on the influence of RH and air temperature on the airborne survival of coronavirus $229 \mathrm{E}$ would tend to suggest otherwise [22].

\section{Sewage and biosolids}

SARS-CoV can survive for up to 96 hours in body fluids such as sputum, feces and serum, but is less stable in urine [20]. The fecal excretion of SARS-CoV generated much concern on the safety of handling and spreading municipal solids on lands [29]. There are no reports of the recovery of infectious SARS-CoV from raw sewage or sludge and if the behavior of other enveloped viruses such as HIV is an indication, it would be highly unlikely that the virus can survive in such wastes long enough to pose any risks to human health. In view of this, it is even less likely that the virus would survive the conventional methods of sewage and biosolids treatment. Therefore, any suggestion of health risk from handling of municipal wastes or their proper disposal would be difficult to justify [29]. 


\section{Skin}

Since safety and ethical considerations would not permit the experimental contamination of the hands of human subjects with SARS-CoV, we have used $229 \mathrm{E}$ as a surrogate to study the potential of coronaviruses to survive on hands. Preliminary findings from such experiments indicate that nearly $45 \%$ of infectious virus remains viable on the hands of adult subjects after 1 hour. This is in contrast to other enveloped respiratory viruses (e.g. parainfluenzavirus) which become essentially undetectable in about 10 minutes on human skin [30].

\section{Food and water}

We are not aware of any published information on the survival of coronaviruses in food. Recent studies have shown SARS-CoV to survive in water to a very limited degree [20]. There is no evidence to suggest the spread of coronaviruses through food or water.

\section{Environmental surfaces}

SARS-CoV [20] and 229E and OC43 [23] can retain their infectivity for several hours on porous and non-porous environmental surfaces. While such survival is better than that of other enveloped human pathogens [30], there is no evidence to suggest that environmental surfaces play any direct or indirect role in the spread of coronaviruses.

\section{Activity of microbicides against coronaviruses}

Because of their enveloped nature coronaviruses are more susceptible to microbicides than non-enveloped viruses. In a comparative study, an animal parvovirus (non-enveloped) required 20- to 500-fold higher concentrations of the tested microbicides than were needed to inactivate an animal coronavirus [31].

Even before the advent of SARS considerable evaluation of the activity of microbicides against this virus group had been carried out. The following is a summary of this information.

Virucidal activity of several microbicides was tested against the mouse hepatitis virus (MHV) and the canine coronavirus (CCV), Kilham rat virus and canine parvovirus [32]. Both coronaviruses were readily inactivated by ethanol, isopropanol, benzalkonium chloride, iodophor, sodium hypochlorite, sodium chlorite, cresol soap and formaldehyde whereas the two parvoviruses proved to be considerably more resistant. 
The relative resistance of $229 \mathrm{E}$ to microbicides was compared to that of coxsackievirus B3, adenovirus type 5, and parainfluenzavirus type 3 using the second tier of a quantitative carrier test (QCT-2) [33]. Stainless steel disks were used as carriers and each one received $10 \mu$ l of the test virus, suspended in either faeces or mucin and the inoculum allowed to dry for $1 \mathrm{~h}$ under ambient conditions. After 1 min exposure to $20 \mu \mathrm{l}$ of the disinfectant, the virus from the disks was immediately eluted and plaque assayed. The efficacy criterion of $a \geq 3 \log _{10}$ reduction in virus infectivity was used. As expected, the coronavirus proved to be generally less resistant to microbicides than the two non-enveloped viruses.

In a more recent study, Wood and Payne [34] used a suspension test to assess the activity of chloroxylenol, benzalkonium chloride and cetrimide/chlorhexidine against three types of enveloped viruses (herpesvirus type 1, HIV-1 and a human coronavirus). The coronavirus was found to be generally more resistant than the other two enveloped viruses tested. While this observation is of interest, the findings have limited practical significance because the testing was based on a suspension test which presents the test microbicide with a weaker challenge than a carrier test protocol. A summary of all findings can be found in Table 2.

\section{Alcohols}

Most alcohols used in disinfection are ethanol and isopropyl alcohol, both usually at a concentration of $70 \%[32,34]$. Without soil load, the transmissible gastroenteritis virus (TGEV) was reduced $4.5 \log _{10}$ by ethanol in the suspension test over 5 minutes [35]. Similarly, using QCT-2 and organic load, ethanol reduced 229E [33] by at least $3 \log 10$ over the course of 5 minutes.

\section{Chlorine and other halides}

In tests using varying concentrations of sodium hypochlorite, $1000 \mathrm{ppm}$ was effective against TGEV [34], bovine coronavirus [31] and 229E [33] irrespective of test conditions. Chloramine $\mathrm{T}\left(\mathrm{C}_{7} \mathrm{H}_{7} \mathrm{SO}_{2} \mathrm{NNaCl}\right)$ had similar results against bovine coronavirus and 229E. Povidone-iodine at a concentration of $1 \%$ reduced $229 \mathrm{E}$ by $>3 \log _{10}$ with the QCT-2 test.

\section{Aldehydes}

Formaldehyde at $4 \%$ is used as an overall disinfecting and sterilizing solution albeit its use as a general disinfectant is not recommended. It is effective against TGEV, reducing it over $5 \log _{10}$ in under 5 minutes in suspension. At $2 \%$, glutaraldehyde can inactivate $229 \mathrm{E}$ over $3 \log _{10}$ [33] in the QCT-2 test. 
Table 2. Effect of microbicides on coronaviruses

\begin{tabular}{|c|c|c|c|c|c|}
\hline Active ingredient(s) & Virus & Test condition & Time & $\begin{array}{l}\geq 3 \log _{10} \\
\text { reduction }\end{array}$ & Refs. \\
\hline \multicolumn{6}{|c|}{ Ethanol } \\
\hline $70 \%$ & $229 \mathrm{E}$ & $\mathrm{QCT}-2+\mathrm{SL}$ & $5 \min$ & Yes & {$[32]$} \\
\hline $70 \%$ & TGEV & Suspension & $5 \min$ & Yes & [34] \\
\hline \multicolumn{6}{|c|}{ Chlorine } \\
\hline Sodium hypochlorite (100 ppm) & $229 \mathrm{E}$ & $\mathrm{QCT}-2+\mathrm{SL}$ & $5 \min$ & No & [32] \\
\hline Sodium hypochlorite (1000 ppm) & $229 \mathrm{E}$ & $\mathrm{QCT}-2+\mathrm{SL}$ & $5 \mathrm{~min}$ & Yes & [32] \\
\hline Sodium hypochlorite (1500 ppm) & TGEV & Suspension & $5 \mathrm{~min}$ & Yes & [34] \\
\hline Chloramine T (1500 ppm) & $229 \mathrm{E}$ & $\mathrm{QCT}-2+\mathrm{SL}$ & $5 \min$ & & {$[32]$} \\
\hline \multicolumn{6}{|c|}{ Iodine } \\
\hline $1 \%$ & $229 \mathrm{E}$ & $\mathrm{QCT}-2+\mathrm{SL}$ & $5 \mathrm{~min}$ & Yes & {$[32]$} \\
\hline $1 \%$ & TGEV & Suspension & $5 \mathrm{~min}$ & Yes & [34] \\
\hline $0.5 \%$ & Bovine & Suspension + SL & $60 \mathrm{~min}$ & Yes & {$[30]$} \\
\hline \multicolumn{6}{|c|}{ Formaldehyde } \\
\hline $0.3 \%$ & Bovine & Suspension + SL & $60 \mathrm{~min}$ & Yes & {$[30]$} \\
\hline \multicolumn{6}{|c|}{ Glutaraldehyde } \\
\hline $2 \%$ & $229 \mathrm{E}$ & $\mathrm{QCT}-2+\mathrm{SL}$ & $5 \mathrm{~min}$ & & {$[32]$} \\
\hline $2 \%$ & TGEV & Suspension & $5 \mathrm{~min}$ & Yes & {$[34]$} \\
\hline \multicolumn{6}{|c|}{ Quaternary ammonium compounds - benzalkonium chloride } \\
\hline 100 ppm & TGEV & Suspension & $5 \mathrm{~min}$ & Yes & {$[34]$} \\
\hline \multicolumn{6}{|c|}{ Chlorhexidene gluconate } \\
\hline 80 ppm & $229 \mathrm{E}$ & QCT-2 + SL & $5 \mathrm{~min}$ & No & {$[32]$} \\
\hline $80 \mathrm{ppm}+70 \%$ ethanol & $229 \mathrm{E}$ & $\mathrm{QCT}-2+\mathrm{SL}$ & $5 \mathrm{~min}$ & Yes & {$[32]$} \\
\hline \multicolumn{6}{|c|}{ Phenolics } \\
\hline$O$-phenylphenol (200 ppm) & $229 \mathrm{E}$ & QCT-2 + SL & $5 \mathrm{~min}$ & No & {$[32]$} \\
\hline$O$-phenylphenol + sodium lauryl & $229 F$ & -5 & - & & [32] \\
\hline$O$-phenylphenol $+70 \%$ ethanol & $229 \mathrm{E}$ & $\mathrm{QCT}-2+\mathrm{SL}$ & $5 \mathrm{~min}$ & $\begin{array}{l}\text { Yes } \\
\text { Yes }\end{array}$ & {$[32]$} \\
\hline $\begin{array}{l}O \text {-phenylphenol }+5 \% \text { isopropyl } \\
\text { alcohol }\end{array}$ & TGEV & $\mathrm{QCT}-2+\mathrm{SL}$ & $5 \mathrm{~min}$ & Yes & {$[34]$} \\
\hline
\end{tabular}

SL, soil load; QCT-2, quantitative carrier test - Tier 2; TGEV, transmissible gastroenteritis virus

\section{Quaternary ammonium compounds}

A quaternary ammonium disinfectant requires the presence of an ammonium ion and at least one of its hydrogen atoms substituted by an organic radical. As a result, the list of quaternary ammonium compounds is rather extensive. This type of disinfectant is usually cationic and affects a 
Table 3. Data on stability and resistance of SARS-CoV compiled by members of WHO laboratory network (modified from [35])

\begin{tabular}{|c|c|c|c|c|}
\hline Substrate & $\begin{array}{l}\text { Initial viral } \\
\text { count } \log _{10} \\
\text { PFU }\end{array}$ & Condition & $\begin{array}{l}\text { Survival } \\
\text { time }\end{array}$ & $\begin{array}{l}\text { Method of } \\
\text { testing viability }\end{array}$ \\
\hline
\end{tabular}

\section{Government Virus Unit, Dept. of Health, Hong Kong, SAR China}

\begin{tabular}{lllll}
$\begin{array}{l}\text { Virus spiked in baby } \\
\text { stool }\end{array}$ & $1.00 \mathrm{E}+03$ & $\mathrm{pH} 6-7$ & $3 \mathrm{hr}$ & $\begin{array}{l}\text { Virus isolation } \\
\text { in cell culture }\end{array}$ \\
$\begin{array}{l}\text { Virus spiked in } \\
\text { normal stool }\end{array}$ & $7.50 \mathrm{E}+03$ & $\mathrm{pH} 8$ & $6 \mathrm{hr}$ & $\begin{array}{l}\text { Virus isolation } \\
\text { in cell culture }\end{array}$ \\
$\begin{array}{l}\text { Virus in diarrheal stool } \\
\text { 7.50E }+03\end{array}$ & $\mathrm{pH} 9$ & 4 days & $\begin{array}{l}\text { Virus isolation } \\
\text { in cell culture }\end{array}$ \\
\hline
\end{tabular}

\begin{tabular}{|c|c|c|c|c|}
\hline \multicolumn{5}{|c|}{ Queen Mary Hospital, The University of Hong Kong, Hong Kong, SAR China } \\
\hline Stool & $1.00 \mathrm{E}+03$ & $\begin{array}{l}\text { Room } \\
\text { temperature }\end{array}$ & at least 2 days & $\begin{array}{l}\text { Virus isolation } \\
\text { in cell culture }\end{array}$ \\
\hline Urine & $1.00 \mathrm{E}+03$ & $\begin{array}{l}\text { Room } \\
\text { temperature }\end{array}$ & at least $24 \mathrm{hr}$ & $\begin{array}{l}\text { Virus isolation } \\
\text { in cell culture }\end{array}$ \\
\hline $\begin{array}{l}\text { Virus culture medium } \\
+1 \% \text { bovine serum }\end{array}$ & $1.00 \mathrm{E}+03$ & $\begin{array}{l}\text { On plastic } \\
\text { surface in room } \\
\text { temperature }\end{array}$ & at least 2 days & $\begin{array}{l}\text { Virus isolation } \\
\text { in cell culture }\end{array}$ \\
\hline $\begin{array}{l}\text { Virus culture medium } \\
+1 \% \text { bovine serum }\end{array}$ & $1.00 \mathrm{E}+04$ & $30-37^{\circ} \mathrm{C}$ & at least $1 \mathrm{hr}$ & $\begin{array}{l}\text { Virus isolation } \\
\text { in cell culture }\end{array}$ \\
\hline $\begin{array}{l}\text { Virus culture medium } \\
+1 \% \text { fetal calf }\end{array}$ & $1.00 \mathrm{E}+04$ & $56^{\circ} \mathrm{C}$ & $\begin{array}{l}\text { degradation of } \\
\text { serum titre over } \\
\text { time ( } 10000 \\
\text { infectious virus } \\
\text { units in } 15 \text { min })\end{array}$ & $\begin{array}{l}\text { Virus isolation } \\
\text { in cell culture }\end{array}$ \\
\hline $\begin{array}{l}\text { Virus in acetone, } \\
10 \% \text { formaldehyde and } \\
\text { paraformaldehyde, } \\
10 \% \text { clorox, } 75 \% \text { ethanol } \\
2 \% \text { phenol }\end{array}$ & $1.00 \mathrm{E}+06$ & $\begin{array}{l}\text { Room } \\
\text { temperature }\end{array}$ & less than $5 \mathrm{~min}$ & $\begin{array}{l}\text { Virus isolation } \\
\text { in cell culture }\end{array}$ \\
\hline
\end{tabular}

\begin{tabular}{|c|c|c|c|c|c|}
\hline \multicolumn{5}{|c|}{ National Institute of infectious Diseases, Tokyo, Japan } & \multirow{5}{*}{$\begin{array}{l}\text { Virus isolation } \\
\text { and RT-PCR } \\
\text { Virus isolation } \\
\text { and RT-PCR } \\
\text { Virus isolation } \\
\text { and RT-PCR }\end{array}$} \\
\hline $\begin{array}{l}\text { Virus culture } \\
+2 \% \text { bovine serum }\end{array}$ & $1.00 \mathrm{E}+06$ & minus $80^{\circ} \mathrm{C}$ & \multicolumn{2}{|c|}{ at least 4 days } & \\
\hline $\begin{array}{l}\text { Virus culture } \\
+2 \% \text { fetal calf serum }\end{array}$ & $1.00 \mathrm{E}+06$ & $4^{\circ} \mathrm{C}$ & \multicolumn{2}{|c|}{ at least 4 days } & \\
\hline $\begin{array}{l}\text { Virus culture } \\
+2 \% \text { fetal calf serum }\end{array}$ & $1.00 \mathrm{E}+06$ & $37^{\circ} \mathrm{C}$ & \multicolumn{2}{|c|}{ less than 4 days } & \\
\hline $\begin{array}{l}\text { Virus culture } \\
+2 \% \text { fetal calf serum }\end{array}$ & $1.00 \mathrm{E}+05$ & $56^{\circ} \mathrm{C}$ & \multicolumn{2}{|c|}{ less than $30 \mathrm{~min}$} & \\
\hline \multicolumn{6}{|c|}{ University of Marburg, Germany } \\
\hline Virus culture & $1.00 \mathrm{E}+06$ & $4^{\circ} \mathrm{C}$ & at leas & 21 days & Virus isolation \\
\hline Virus culture & $1.00 \mathrm{E}+06$ & minus $80^{\circ} \mathrm{C}$ & at leas & 21 days & Virus isolation \\
\hline \multicolumn{6}{|c|}{\begin{tabular}{lclll} 
& \multicolumn{3}{c}{ Chinese University, Hong Kong } & \\
Virus in phosphate & $9.00 \mathrm{E}+04$ & Room & PBS & Stool \\
buffered saline (PBS) & & temperature on & & \\
Virus in sterilized & & Plastered wall & $24 \mathrm{~h}$ & $36 \mathrm{~h}$ \\
& & Plastic surface & $36 \mathrm{~h}$ & $72 \mathrm{~h}$ \\
& Formica surface & $36 \mathrm{~h}$ & $36 \mathrm{~h}$ \\
& Stainless steel & $36 \mathrm{~h}$ & $72 \mathrm{~h}$ \\
& Wood & $12 \mathrm{~h}$ & $24 \mathrm{~h}$ \\
& Cotton cloth & $12 \mathrm{~h}$ & $24 \mathrm{~h}$ \\
& & Pig skin & $? 24 \mathrm{~h}$ & $? 24 \mathrm{~h}$ \\
& Glass slide & $72 \mathrm{~h}$ & $96 \mathrm{~h}$ \\
& & Paper file cover & $24 \mathrm{~h}$ & $36 \mathrm{~h}$
\end{tabular}} \\
\hline
\end{tabular}


cell by adhering to its negatively charged membrane and disrupting the ionic potential of the cell. In the case of viruses, this adherence can disrupt the envelope, rendering the virus noninfectious. The quaternary ammonium compounds are best represented by chlorhexidine gluconate, which is widely used in health care institutions and in consumer disinfectants and antiseptics. In both suspension and QCT-2 tests, chlorhexidine gluconate faired well against TGEV [35] and 229E [33, 34]. Concentrations ranging from 500 to $15,000 \mathrm{ppm}$ were effective in reducing the virus by at least 3 $\log _{10}$.

\section{Phenolics}

The phenolic compounds have a long history as their ancestry dates back to the use of coal tar soaps, whose active ingredients were creosol-based. Although some disinfectants continue to use the same historical active ingredient, creosol, most have developed over time to become more active against various microbes. For example, $o$-phenylphenol at $200 \mathrm{ppm}$ is highly ineffective against most viruses, including $229 \mathrm{E}$ in the QCT-2 test [33]. However, the addition of either a detergent, such as sodium lauryl sulphate, or ethanol, proves highly effective against the virus over 3 $\log _{10}$ reduction is seen after 5 minutes. In the same way, many phenolic compounds rely on the helper effect of other chemicals to work effectively.

\section{Survival and inactivation of the SARS coronavirus}

The World Health Organization Laboratory Network has summarized the available data on SARS-CoV survival and inactivation [36], which are redrawn for this chapter as Table 3. Tables 4 and 5 summarize more recent studies on the inactivation of $229 \mathrm{E}$ by environmental surface disinfectants and antiseptics, respectively.

\section{Concluding remarks}

Despite the enhanced awareness of the potential of coronaviruses as animal and human pathogens, our understanding of their environmental survival and the exact means of their spread remains weak. Such information would be essential to design and implement more rational approaches to prevention and control of outbreaks of coronaviral infections. This is particularly relevant for the recently discovered SARS-CoV. However, the limited data available indicate that coronaviruses as a group are more stable in the environment that other enveloped viruses. 
Table 4. Activity of microbicides against coronavirus 229E (Sattar et al., unpublished data)

\begin{tabular}{|c|c|c|c|}
\hline Microbicide & Dilution tested (ppm) & Contact time ( $\mathrm{min})$ & $\log _{10}$ reduction \\
\hline Accelerated $\mathrm{H}_{2} \mathrm{O}_{2}$ & Undiluted (5000) & 3 & 4.0 \\
\hline Spray (26 g ethanol + & Undiluted & 3 & 4.4 \\
\hline $\begin{array}{l}11.5 \mathrm{~g} \text { 2-propanol }+ \\
0.054 \mathrm{~g} \text { polyhexanide/100 g) }\end{array}$ & & 1 & 4.4 \\
\hline Ethanol & $75 \%(\mathrm{v} / \mathrm{v})$ & 5 & 4.0 \\
\hline Potassium monopersulfate & $1 \%(\mathrm{w} / \mathrm{v})$ solution & 0.5 & 2.3 \\
\hline $\begin{array}{l}23.0 \%+\text { sodium dichloro-s- } \\
\text { triazinetrione } 5.0 \%\end{array}$ & in water & 1 & 4.1 \\
\hline $\begin{array}{l}5.25 \% \text { sodium hypochlorite } \\
\text { (bleach) }\end{array}$ & $1: 50(1000)$ & 3 & 4.0 \\
\hline $\begin{array}{l}5.25 \% \text { sodium hypochlorite } \\
+5 \% \text { acetic acid (vinegar) }\end{array}$ & $\begin{array}{c}2 \mathrm{ml} 5 \% \text { acid } \\
+8 \mathrm{ml} \text { water }(5000)\end{array}$ & 0.5 & 2.2 \\
\hline Spray (ethanol 79.646\% & Undiluted & 3 & 3.3 \\
\hline + a quat.) & & 10 & 3.1 \\
\hline $4.8 \%$ chloroxylenol & $1: 40(1200)$ & 10 & 4.1 \\
\hline A mixture of two quat. ammonium & ms $1: 128(660)$ & 10 & 4.0 \\
\hline A mixture of two phenolics & $1: 256(820)$ & 10 & 4.1 \\
\hline
\end{tabular}

The second tier of the quantitative carrier test (QCT-2) with stainless steel disks was used. Ten $\mu l$ of the virus suspension with a soil load was dried on each carrier and the inoculum exposed to $50 \mu \mathrm{l}$ of the test microbicide at $23 \pm 2{ }^{\circ} \mathrm{C}$.

Table 5. Activity of an ethanol-based hand rub against coronavirus 229E (Sattar et al., unpublished data)

\begin{tabular}{|c|c|c|}
\hline Treatment & Mean \pm SD & \% Reduction \\
\hline Baseline & $1.32 \times 10^{4} \pm 0.4$ & - \\
\hline Hard water (200 PPM CaCO 3 ) & $3.02 \times 10^{3} \pm 2.0$ & 77.0 \\
\hline $75 \%(\mathrm{v} / \mathrm{v})$ ethanol & 0 & $>99.99$ \\
\hline Ethanol $(60 \%)$ containing gel & 0 & $>99.99$ \\
\hline
\end{tabular}

The fingerpad method (ASTM 1838) was used. Ten $\mu$ l of virus in soil load was placed on each fingerpad \& dried. The dried inoculum was exposed to $1 \mathrm{ml}$ of control or test solution for 30 seconds. The fingerpads were eluted \& eluates plaque assayed.

\section{References}

1 Holmes KV, Lai MMC (1996) Coronaviridae: The viruses and their replication. In: Fields BN, Knipe DM, Howley PM (eds): Virology. Vol. 1. 3rd ed. Philadelphia: Lippincott-Raven, 1075-1093

2 Kapikian AZ (1975) The coronaviruses. Dev Biol Stand 28: 42-64

3 International Committee on Taxonomy of Viruses. ICTV Index to Virus Classification and Nomenclature. http://www.ncbi.nlm.nih.gov/ICTVdb/Ictv/ index.htm.

4 Grattan DA (1968) Infectious bronchitis in laying fowls. Vet Rec 83: 157 
5 King DJ (1975) Comments on the etiology and immunity of transmissible (coronaviral) enteritis of turkeys (bluecomb). Am J Vet Res 36: 555-556

6 Rota PA, Oberste MS, Monroe SS, Nix WA, Campagnoli R, Icenogle JP, Penaranda S, Bankamp B, Maher K, Chen MH et al (2003) Characterization of a novel coronavirus associated with severe acute respiratory syndrome. Science 300: 1394-1399

7 Stavrinides J, Guttman DS (2004) Mosaic evolution of the severe acute respiratory syndrome coronavirus. $J$ Virol 78: 76-82

8 World Health Organization. Severe acute respiratory syndrome (SARS) Report by the Secretariat. Nov. 23, 2003 EB113/33. http: //www.who.int/gb/ EB_WHA/PDF/EB113/eeb11333.pdf 8422 and 908

9 Brown EG, Tetro JA (2003) Comparative analysis of the SARS coronavirus genome: a good start to a long journey. Lancet 361: 1756-1757

10 Chandler C (2003) SARS attacks, China shudders. Fortune 147: 32

11 Leung WK, To KF, Chan PK, Chan HL, Wu AK, Lee N, Yuen KY, Sung JJ (2003) Enteric involvement of severe acute respiratory syndrome-associated coronavirus infection. Gastroenterology 125: 1011-1017

12 Bourgueil E, Hutet E, Cariolet R, Vannier P (1992) Experimental infection of pigs with the porcine respiratory coronavirus (PRCV): measure of viral excretion. Vet Microbiol 31: 11-18

13 Inouye S (2003) SARS transmission: language and droplet production. Lancet 362: 170

14 Olsen SJ, Chang HL, Cheung TY, Tang AF, Fisk TL, Ooi SP, Kuo HW, Jiang DD, Chen KT, Lando J et al (2003) Transmission of the severe acute respiratory syndrome on aircraft. $N$ Engl J Med 349: 2416-2422

15 Wong GW, Fok TF (2004) Severe acute respiratory syndrome (sars) in children. Pediatr Pulmonol 37 (S26): 69-71

16 Kennedy M, Citino S, McNabb AH, Moffatt AS, Gertz K, Kania S (2002) Detection of feline coronavirus in captive Felidae in the USA. J Vet Diagn Invest 14: 520-522

17 Hasoksuz M, Hoet AE, Loerch SC, Wittum TE, Nielsen PR, Saif LJ (2002) Detection of respiratory and enteric shedding of bovine coronaviruses in cattle in an Ohio feedlot. $J$ Vet Diagn Invest 14: 308-313

18 Van Reeth K, Nauwynck H, Pensaert M (1996) Dual infections of feeder pigs with porcine reproductive and respiratory syndrome virus followed by porcine respiratory coronavirus or swine influenza virus: a clinical and virological study.Vet Microbiol 48: 325-335

19 Hoet AE, Smiley J, Thomas C, Nielsen PR, Wittum TE, Saif LJ (2003) Association of enteric shedding of bovine torovirus (Breda virus) and other enteropathogens with diarrhea in veal calves. Am J Vet Res 64: 485-490

20 Duan SM, Zhao XS, Wen RF, Huang JJ, Pi GH, Zhang SX, Han J, Bi SL, Ruan L, Dong XP; SARS Research Team (2003) Stability of SARS coronavirus in human specimens and environment and its sensitivity to heating and UV irradiation. Biomed Environ Sci 16: 246-255

21 Cho KO, Hoet AE, Loerch SC, Wittum TE, Saif LJ (2001) Evaluation of con- 
current shedding of bovine coronavirus via the respiratory tract and enteric route in feedlot cattle. Am J Vet Res 62: 1436-1441

22 Ijaz MK, Brunner AH, Sattar SA, Nair RC, Johnson-Lussenburg CM (1985) Survival characteristics of airborne human coronavirus 229E. J Gen Virol 66: 2743-2748

23 Sizun J, Yu MW, Talbot PJ (2000) Survival of human coronaviruses 229E and OC43 in suspension and after drying onsurfaces: a possible source ofhospitalacquired infections. $J$ Hosp Infect 46: 55-60

24 Ng SK (2004) The mystery of Amoy Gardens. In: Loh C. and Civic Exchange (eds): At the Epicentre: Hong Kong and the SARS Outbreak. Hong Kong: Hong Kong University Press, 117-138

$25 \mathrm{Ng}$ SK (2003) Possible role of an animal vector in the SARS outbreak at Amoy Gardens. Lancet 362: 570-572

26 Peters CJ, Khan AS (2002) Hantavirus pulmonary syndrome: the new American hemorrhagic fever. Clin Infect Dis 34: 1224-1231

27 Yu ITS, Li Y, Wong TW, Tam W, Chan AT, Lee JH, Leung DY, Ho T (2004) Evidence of airborne transmission of the severe acute respiratory syndrome virus. $N$ Eng J Med 350: 1731-1739

28 Somogyi R, Vesely AE, Azami T, Preiss D, Fisher J, Correia J, Fowler RA (2004) Dispersal of respiratory droplets with open vs closed oxygen delivery masks: implications for the transmission of severe acute respiratory syndrome. Chest 125: 1155-1157

29 Environmental Science \& Engineering Magazine. Biosolids not affected by SARS virus. Environ Sci Eng June, 2003, http: //www.esemag.com/0603/ sars.html

30 Sattar SA, Springthorpe VS (1996) Transmission of viral infections through animate and inanimate surfaces and infection control through chemical disinfection. In: C Hurst (ed): Modeling Disease Transmission and Its Prevention by Disinfection. Cambridge University Press, Cambridge, UK, 224-257

31 Maris P (1990) Virucidal efficacy of eight disinfectants against pneumovirus, coronavirus and parvovirus. Ann Rech Vet 21:275-279

32 Saknimit M, Inatsuki I, Sugiyama Y, Yagami K (1988) Virucidal efficacy of physico-chemical treatments against coronaviruses and parvoviruses of laboratory animals. Jikken Dobutsu 37: 341-345

33 Sattar SA, Springthorpe VS, Karim Y, Loro P (1989) Chemical disinfection of non-porous inanimate surfaces experimentally contaminated with four human pathogenic viruses. Epidemiol Infect 102: 493-505

34 Wood A, Payne D (1998) The action of three antiseptics/disinfectants against enveloped and non-enveloped viruses. J Hosp Infect 38: 283-295

35 Brown TT Jr (1981) Laboratory evaluation of selected disinfectants as virucidal agents against porcine parvovirus, pseudorabies virus, and transmissible gastroenteritis virus. Am J Vet Res 42: 1033-1036

36 World Health Organization. First data on stability and resistance of SARS coronavirus compiled by members of WHO laboratory network. http: //www.who.int/csr/sars/survival_2003_05_04/en/ 